\title{
LOWER NORTH BATTERY - DEFENDED PORT OF SIMON'S TOWN
}

\section{Lt-Cdr W. M. Bisset*}

In $1975 \mathrm{Mr} \mathrm{H}$. C. Willis suggested to the present writer that the SA Navy should mount a bronze plaque similar to those commissioned by the Simon's Town Historical Society and displayed on certain historical buildings in the town at Lower North Battery to make people more aware of its long and fascinating history. Although a number of the Simon's Town Port Record Books have been traced, that for Lower North Battery still cannot be found and important gaps in our knowledge of the battery's history remain. Until these can be filled it is felt that it would be unwise to mount the plaque. Nonetheless, some valuable information has been traced and it is important that this should be placed on record.
The predecessor of Lower North Battery, Zoutman Battery, was built on the orders of Commissioner-General A. J. Sluysken in 1793 by Captain Louis Michel Thibault who complained that he was ordered to do so 'always according to niggardly plans and with economy'. ${ }^{1}$ The battery was armed with four 24-pounder guns. On 1 July 1795 the Dutch garrison at Simon's Town spiked their guns and withdrew to Muizenberg. Fortunately for the British Forces the guns were 'very imperfectly' spiked. ${ }^{2}$ After the Dutch surrender, Major-General J. H. Craig immediately set about improving the defences of the Cape, however the Dutch armament of the North Battery, as the battery now became known, was not changed.

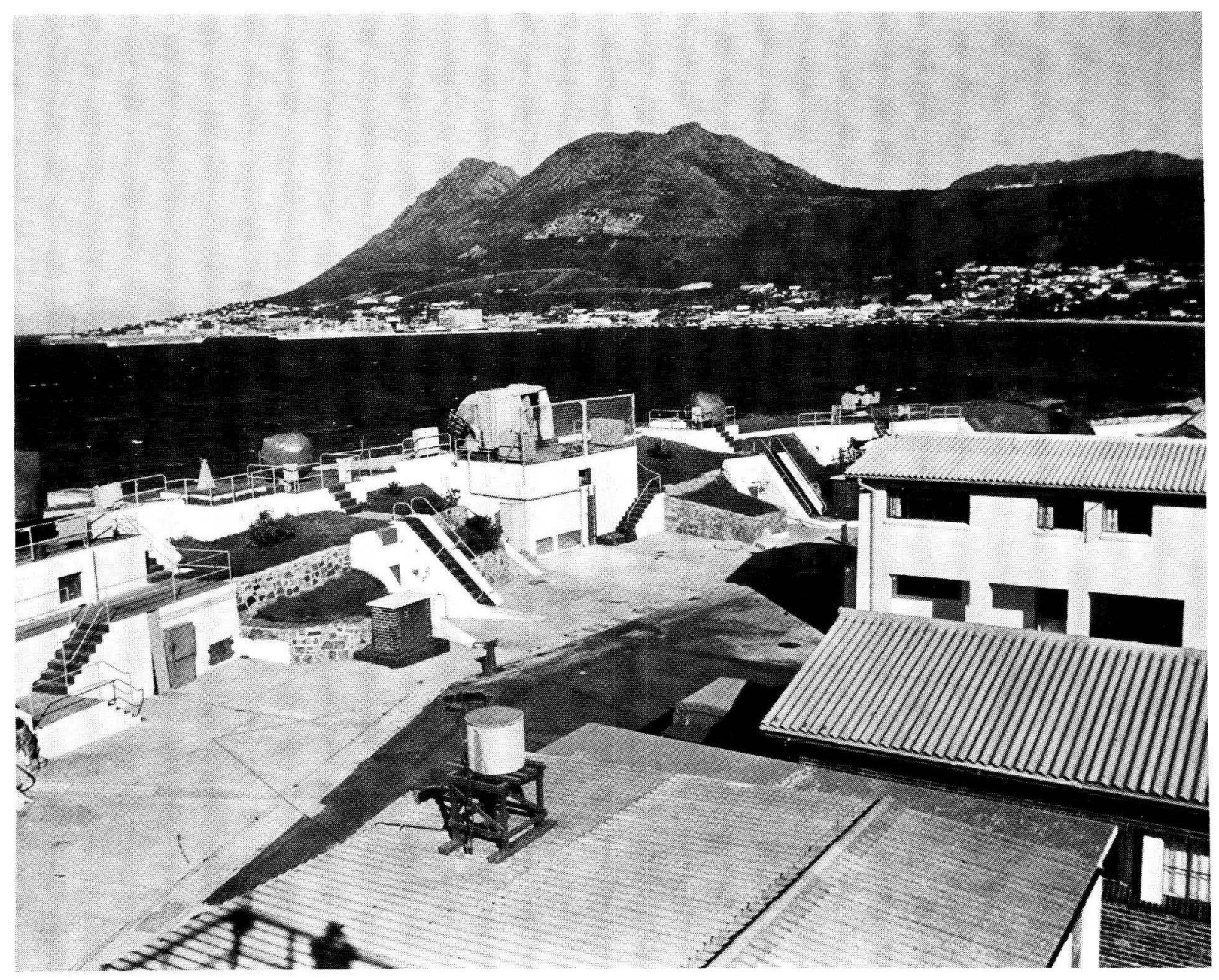

A recent photograph of Lower North Battery, Simon's Town 
In a letter to Lord Castlereagh, Secretary of State for War and Colonies, dated 20 March 1806 Lieutenant-General Sir David Baird the Acting Governor of the Cape Colony wrote that he had considered it advisable to repair the batteries in Table Bay and Simon's Bay as far as possible. Since those in Simon's Bay had been completely destroyed he added that this would be 'attended with some expense'.3

A plan of Simon's Bay dated September 1806 shows a 'permanent battery containing 5 guns and one 13-inch mortar on the North Point of Simon's Bay'. On 31 October 1809 the permanent North Battery was armed with three English iron 18-pounders and two English iron 12pounders ${ }^{4}$. By 1 December 1810 the armament of the battery had been changed to five English iron 18-pounders. ${ }^{5}$

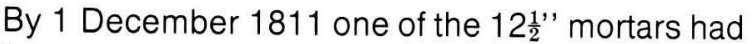
been moved from the South Battery to the North Battery. ${ }^{6}$ On 30 April 1813 the North Battery was armed with three English iron 18-pounders and one Dutch brass $12 \frac{1}{2}$ " mortar. The ordnance for the two batteries in Simon's Town was supplied with 813 rounds of ammunition in a permanent magazine mounted on wood platforms in good order'?

On 1 August 1820 iron gun carriages for the Simon's Town batteries were landed from the SIR GEORGE OSBORNE, a transport. ${ }^{8}$ In 1830 a sudden crisis necessitated the dispatch of the Cape Squadron to Mauritius and highlighted the unprotected state of the Simon's Bay naval base. Commodore C. M. Schomberg described the North or infilading Battery as 'being in ruins, and in a state of abandonment'. The Governor of the Cape Colony, Lieutenant-General Sir Lowry Cole, immediately took steps to improve the Simon's Town defence and these included the renovation of the North Battery. ${ }^{9}$

On the morning of 5 March 1861 a committee of officers assembled at Simon's Town to 'bring forward a project for the defence of the Cape Peninsula'. The committee recommended that the North Battery be 'entirely reconstructed' and issued with six 32-pounders. According to Appendix No 2 of this report the existing armament of the battery was six 8 -pounders. ${ }^{10}$

In 1867 the Cape Town and Simon's Town defences were armed with 92 smooth bore guns. ${ }^{11}$ In the Annual Report of the Board of Ordnance for 1867 the works at Simon's Town were described as being in 'bad condition and quite unfit to resist the projectiles at present in use'. The batteries were fully armed with 19 pieces of smooth bore ordnance in serviceable condition. Twenty four smooth bore guns were held in reserve by the Store Department. The report states that there were no 6-pounder Armstrong guns at Simon's Town and that the artillery force was inadequate.

The Report for the following year describes the fortifications of the Cape as 'insufficient for defence in the present state of artillery science'. The North Battery, Simon's Town is listed as one of the two batteries which were not 'fully armed'. There were 31 smooth-bore guns at Simon's Town manned by an inadequate force of gunners. By 1881 there were 12 Rifled Muzzle Loading guns, 2 smooth-bore guns converted to R.M.L. and 66 smooth-bores at Cape Town and Simon's Town. ${ }^{12}$ In May 1883 the defence of Simon's Bay consisted of four batteries armed with 10 rifled and 8 smooth-bore guns. ${ }^{13}$

In a letter to the Deputy Adjutant-General in South Africa dated 10 March 1883 the Officer Commanding Royal Artillery in South Africa, Lieutenant-Colonel A. A. Stewart, mentioned the unprotected state of the North Battery at Simon's Town and the insecure state of the cartridge and shell stores there which required gates at the entrances of the passages leading to the issuing hatches and lamp recesses.

Regulations stipulated that 'each rifled gun should be provided with 100 rounds of ammunition ready made up for immediate use with a proportion of filled shells' and at the North Battery this had been done. Because of insufficient magazine accommodation or cartridge and shell stores which were insecure this had not been done elsewhere in the District.

A further important weakness which applied to all the Simon's Town batteries mentioned by Colonel Stewart was that they were 'commanded from the hills in rear which are accessible to landing parties from the opposite coast'. In 1885-1886 the battery was extensively rebuilt and re-armed with rifled guns. ${ }^{14}$

In January 1906 Field Marshal HRH the Duke of Connaught, the Inspector-General of the Forces, inspected the Simon's Town defences. The Duke was accompanied by General Hildyard, the General Officer Commanding the Forces in South Africa and Generals Maxwell and E. S. Brook. 


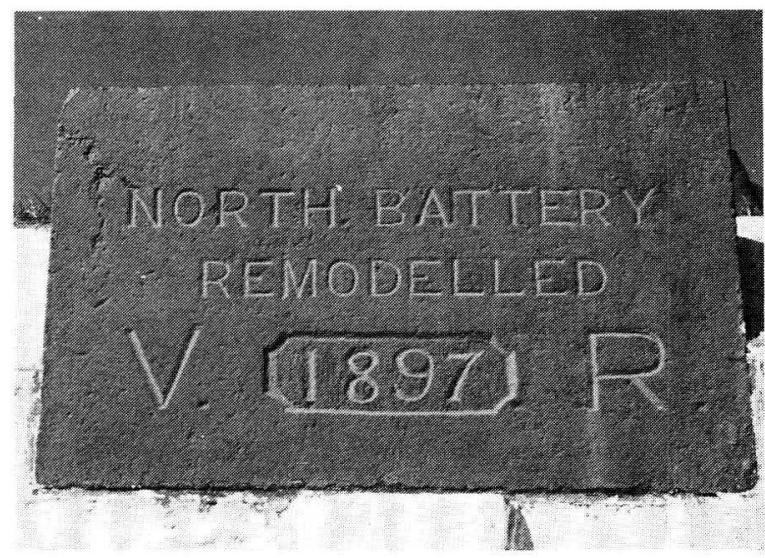

This reminder that the battery was remodelled in 1897 has survived.

After arriving at Simon's Town by train, the Duke inspected a Guard of Honour at the Station and then he and his mounted entourage cantered up to the Lower North Battery where No 4 Company of the Cape Garrison Artillery under Captain Black and Lieutenant Adams were manning the battery of 4.7 -inch guns. The volunteers then engaged a target towed by a tug and 'taking everything into consideration, acquitted themselves excellently'. ${ }^{15}$

In 1908 there were two fighting lights near Lower North Battery. Major-General J. C. Dalton, Inspector, Royal Garrison Artillery 1906-1910, reported that he saw them working on the night of 27 February 1908 and that they were 'not very satisfactory' since there was no directing station, no communication between the Battery Commander and the lights and the projectors had to be traversed by hand. ${ }^{16}$

Records in the SA Defence Force Archives reveal that Lower North Battery was manned by 16 men of the Royal Engineers in 1911 and that it was used as a drill and practice battery. During the First World War the Simon's Town defences were manned by Number 84 and 97 Companies of the Royal Garrison Artillery and the Cape Garrison Artillery. Number 97 Company RGA sailed for Europe in May 1916.

The armament of Simon's Bay is listed as three 9,2-inch guns. ${ }^{17}$ During the First World War two 6-pounder Hotchkiss Q. F. guns mounted on cone pedestals were 'constantly moved between Queen's Battery and Lower North Battery and were finally taken in for storage at Main Barracks in November $1925^{\prime} .{ }^{18}$

On 1 December 1921 Lower North Battery was

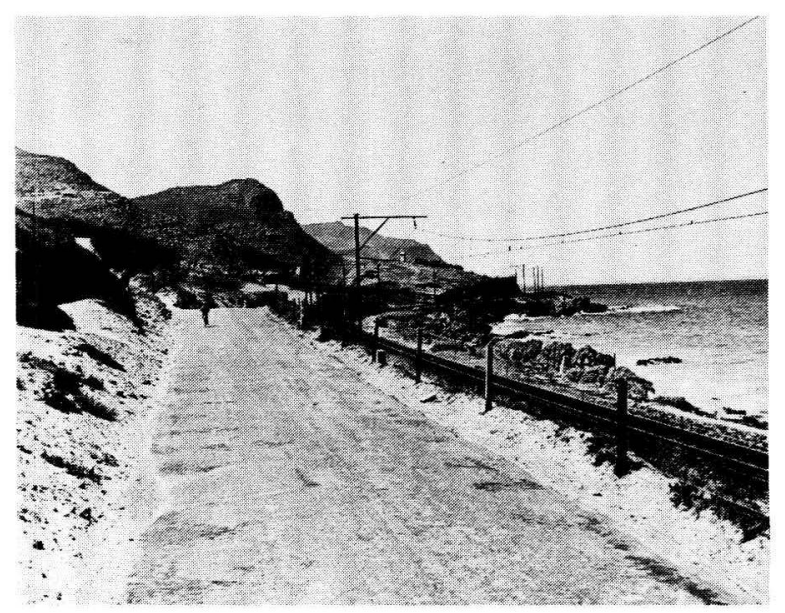

Lower North Battery seen from the main road from Simon's Town to Cape Town. Before the advent of the railway line, the road ran between the battery and the sea.

transferred to the Government of the Union of South Africa in terms of Act No 33 of 1922. Brigadier Maurice de Villiers has recorded that the two Quick Firing 4.7-inch guns which had previously been mounted there had been dismounted and that the battery was on loan to the Royal Navy as a torpedo warhead store. ${ }^{19}$

During the years when Lower North was the unarmed Lights Station for the northern batteries at Simon's Town, it was known as Lower North Emplacement. The Fortress Manning reports are a most important source of information concerning the history of the Cape Peninsula Defences.

On 14 April 1927, the Staff Officer 'Q' of No 1 Military District wrote that the 'bad state of the projectors in the Lower North Emplacement rendered that pair of lights of little or no value'. Two new $90 \mathrm{~cm}$ mirrors for the projectors were urgently required.

In a letter to the Chief of the General Staff dated 30 June 1928, the Officer Commanding No 1 Military District wrote that the Lower North Lights did not cover the Examination Anchorage and that it would therefore be necessary to retain the lights at Queen's Battery also. He added that the acquisition of new mirrors could be delayed if necessary.

In his report on the Manning of the Cape Peninsula Defences in March 1929, the officer Commanding SA Permanent Garrison Artillery, Lieutenant-Colonel B. C. Judd, OBE records that the Defence Electric Light Emplacements at Lower North were manned by the Cape Fortress Engineers who were quartered at Main Barracks, 


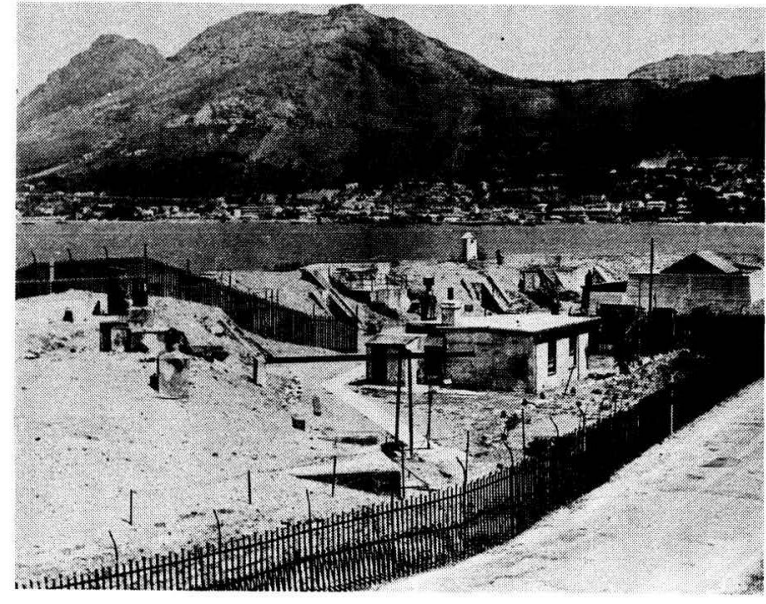

Lower North, disarmed circa 1946.

Simon's Town from 18-27 March 1929.

Colonel Judd reported that the two mirrors in one of the Lower North Emplacements were 'indifferent' and recommended that they be resilvered at Chatham Dockyard. The mirrors were dispatched to HM Dockyard Devonport in HMS LOWESTOFT and returned in HMS CARLISLE on 19 December 1929. However after use in one all night run in March 1930 it was found that the silvering on both had begun to peel and an offer to resilver the mirrors by the Plate Glass Bevelling and Silvering Co Ltd, in Cape Town free of charge was accepted. Tests on one of the mirrors resilvered by the Company were carried out under severe conditions at Mouille Point and proved satisfactory with the exception of the edges which had been backed with a protective paint.

In 1928 the only Dockyard Police outstation was at Lower North Battery. Here one constable would perform guard duty for a month at a time. Since no transport to the battery was provided, three days time off in lieu of travelling were granted..$^{20}$

Colonel D. E. Peddle most kindly provided some notes concerning the battery. Early in 1939 there were two coast artillery searchlights in the battery which were used in conjunction with the two QF 6 -inch guns at Middle North Battery. In about November 1939 a Quick Firing 4.7-inch gun was mounted and two Quick Firing 12-pounder $12 \mathrm{cwt}$ guns were added later on. (The British 12pounder was used to counter a light close defence threat from 1894 to 1957).

However an official return of the present and proposed allotment of coast defence guns and defence electric lights dated 16 April 1940 indicates that the then present allotment for
Lower North Battery was one 12-pounder. The 'Most Secret' order of battle of the Cape Fortress confirms that the Lower North Battery was later armed with one 12-pounder and one 4.7-inch gun. The Simon's Bay Fire Commander was Lieutenant-Colonel J. C. Moolman, MC, 2 Heavy Battery, SA Artillery. The remarks concerning the guns on another document are 'mounted in reserve, NOT manned'. The Cape Fortress Location List dated 4 August 1944 reveals that Lower North Battery was then being used by the Royal Navy.

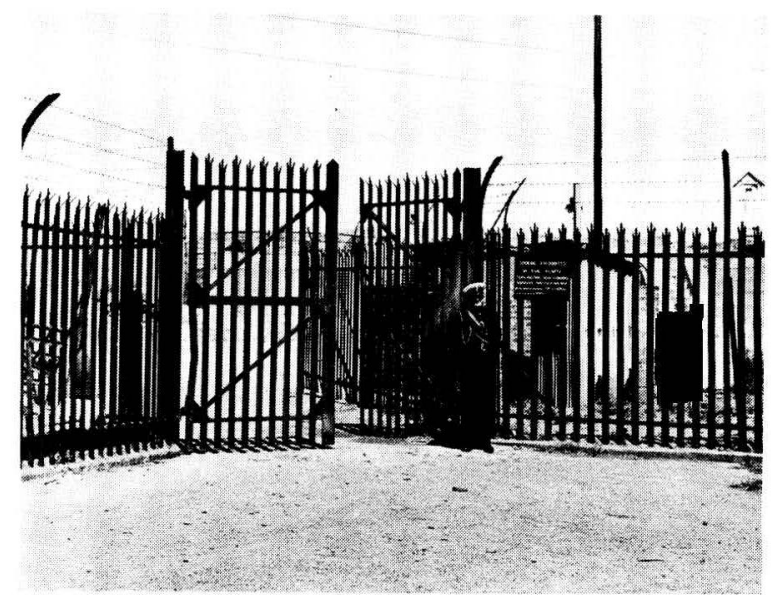

The entrance to Lower North Battery guarded by a Dockyard policeman circa 1946.

An inventory of ordnance dated circa 1952 reveals that the registered numbers of the two 12-pounders at Lower North Battery were 2439 and 2400. In 1957 these two guns and two others (6439 and 2441) were moved to Upper North Battery and they were still there in April 1981. They are visible from the Main Road.

In 1955 the SA Corps of Marines was disbanded and in 1957 the SA Navy's Gunnery School moved from Salisbury Island in Durban to Simon's Town. In 1962 Lower North Battery was re-armed and became the Gunnery School's firing range.

Although the battery has been rebuilt and disarmed from time to time, it has the distinction of being the oldest fortification in South Africa which is still armed.

* Lt Cdr W. M. Bisset, is SO Military Musea, WP Command.

\section{Endnotes}

1. H. R. de Puyfontaine, Louis Michel Thibault 1750-1815 His Official Life at the Cape of Good Hope. Cape Town 1972 p 6. 
2. H. C. Willis, 'The Fortifications of Simon's Bay' in Simon's Town Historical Society Bulletin Vol II No 4, July 1973, p 130

3. G. M. Theal (Ed), Records of the Cape Colony 1793-1827, Vol V p 380 .

4. Report of the State of the Forts and Batteries and Field Ordnance comprising the Ordance Establishment in the Colony of Good Hope dated 31 October 1809.

5. Ibid dated 1 December 1810.

6. Ibid dated 1 December 1811.

7. Ibid dated 30 April 1813

8. H. C. Willis, op cit, $p 130$

9. Ibid, p 131.

10. Report of Committee on Coast Defence 1861

11. Colonel K. W. Maurice-Jones, The History of Coast Artillery in the British Army, London 1959 p 170.
12. Ibid.

13. Letter from Lieutenant-Colonel A. A. Stewart, Commanding Royal Artillery, South Africa to Deputy Adjutant-General Cape Town dated 11th May 1883.

14. Cape Cape Archives plans Inv No M 1/99-108 and article in the Wynberg Times dated 21 August 1886.

15. Undated press cutting in HMS CRESCENT press cutting book circa January 1906.

16. Report by the Inspector of Royal Garrison Artillery on his Inspection of the Royal Garrison Artillery, Cape Colony District 1908 p 8.

17. Colonel K. W. Maurice-Jones op cit, p 190.

18. Queen's Battery Fort Record Book. (Army Book 360).

19. M. V. (Brigadier M. de Villiers), 'Those were the days' in Commando August 1953 p 41.

20. SA Navy News Vol 1 No 7 December 1966 p 16. 